\title{
Why Minimal Guidance During Instruction Does Not Work: An Analysis of the Failure of Constructivist, Discovery, Problem-Based, Experiential, and Inquiry- Based teaching
}

Citation for published version (APA):

Kirschner, P. A., Sweller, J., \& Clark, R. (2016). Why Minimal Guidance During Instruction Does Not Work: An Analysis of the Failure of Constructivist, Discovery, Problem-Based, Experiential, and Inquiry-Based teaching. Educational Psychologist, 41(2), 75-86. https://doi.org/10.1207/s15326985ep4102_1

DOI:

10.1207/s15326985ep4102_1

Document status and date:

Published: 09/06/2016

Document Version:

Other version

Please check the document version of this publication:

- A submitted manuscript is the version of the article upon submission and before peer-review. There can be important differences between the submitted version and the official published version of record. People interested in the research are advised to contact the author for the final version of the publication, or visit the DOI to the publisher's website.

- The final author version and the galley proof are versions of the publication after peer review.

- The final published version features the final layout of the paper including the volume, issue and page numbers.

Link to publication

\section{General rights}

Copyright and moral rights for the publications made accessible in the public portal are retained by the authors and/or other copyright owners and it is a condition of accessing publications that users recognise and abide by the legal requirements associated with these rights.

- Users may download and print one copy of any publication from the public portal for the purpose of private study or research.

- You may not further distribute the material or use it for any profit-making activity or commercial gain

- You may freely distribute the URL identifying the publication in the public portal.

If the publication is distributed under the terms of Article 25fa of the Dutch Copyright Act, indicated by the "Taverne" license above, please follow below link for the End User Agreement:

https://www.ou.nl/taverne-agreement

Take down policy

If you believe that this document breaches copyright please contact us at:

pure-support@ou.nl

providing details and we will investigate your claim.

Downloaded from https://research.ou.nl/ on date: 26 Apr. 2023 


\title{
Why Minimal Guidance During Instruction Does Not Work: An Analysis of the Failure of Constructivist, Discovery, Problem-Based, Experiential, and Inquiry-Based Teaching
}

\author{
Paul A. Kirschner \\ Educational Technology Expertise Center \\ Open University of the Netherlands \\ Research Centre Learning in Interaction \\ Utrecht University, The Netherlands \\ John Sweller \\ School of Education \\ University of New South Wales \\ Richard E. Clark \\ Rossier School of Education \\ University of Southern California
}

\begin{abstract}
Evidence for the superiority of guided instruction is explained in the context of our knowledge of human cognitive architecture, expert-novice differences, and cognitive load. Although unguided or minimally guided instructional approaches are very popular and intuitively appealing, the point is made that these approaches ignore both the structures that constitute human cognitive architecture and evidence from empirical studies over the past half-century that consistently indicate that minimally guided instruction is less effective and less efficient than instructional approaches that place a strong emphasis on guidance of the student learning process. The advantage of guidance begins to recede only when learners have sufficiently high prior knowledge to provide "internal" guidance. Recent developments in instructional research and instructional design models that support guidance during instruction are briefly described.
\end{abstract}

Disputes about the impact of instructional guidance during teaching have been ongoing for at least the past half-century (Ausubel, 1964; Craig, 1956; Mayer, 2004; Shulman \& Keisler, 1966). On one side of this argument are those advocating the hypothesis that people learn best in an unguided or minimally guided environment, generally defined as one in which learners, rather than being presented with essential information, must discover or construct essential information for themselves (e.g., Bruner, 1961; Papert, 1980; Steffe \& Gale, 1995). On the other side are those suggesting that novice learners should be provided with direct instructional guidance on the concepts and procedures required by a particular discipline and should not be left to discover those pro-

Correspondence should be addressed to Paul A. Kirschner, Research Centre Learning in Interaction, Utrecht University, The Netherlands, P.O. Box 80140,3508TC,Utrecht, The Netherlands.E-mail:p.a.kirschner@fss.uu.nl cedures by themselves (e.g., Cronbach \& Snow, 1977; Klahr \& Nigam, 2004; Mayer, 2004; Shulman \& Keisler, 1966; Sweller, 2003). Direct instructional guidance is defined as providing information that fully explains the concepts and procedures that students are required to learn as well as learning strategy support that is compatible with human cognitive architecture. Learning, in turn, is defined as a change in long-term memory.

The minimally guided approach has been called by various names including discovery learning (Anthony, 1973; Bruner, 1961); problem-based learning (PBL; Barrows \& Tamblyn, 1980; Schmidt, 1983), inquiry learning (Papert, 1980; Rutherford, 1964), experiential learning (Boud, Keogh, \& Walker, 1985; Kolb \& Fry, 1975), and constructivist learning (Jonassen, 1991; Steffe \& Gale, 1995). Examples of applications of these differently named but essentially pedagogically equivalent approaches include 